\title{
Manajemen Penerimaan Peserta Didik Baru Secara Online di SMPN 3 Kota Palangka Raya
}

\author{
Rudie \\ Institut Agama Kristen Negeri Palangka Raya \\ Email: rudielautt64@gmail.com
}

\begin{abstract}
This research aims to describe the management of the acceptance of new learners online in the era of the covid 19 pandemic in SMP Negeri 3 Palangka Raya. The problem raises the management of new student admissions conducted online. To map the management problems, researchers highlight aspects of planning (planning), organizing (organizing), leadership (leading), directing, driving (actuating), and control (controling). The research method using qualitative approach, which produces description data, is carried out by means of observation, documentation and interviews with principals and teachers involved in the admission committee of new learners in Christian Junior High School and State Junior High School 3 Palangka Raya Year of study 2020/2021.
\end{abstract}

Keywords: management; new learners; Online

\begin{abstract}
Abstrak
Penelitian ini bertujuan untuk mendeskripsikan manajemen penerimaan peserta didik baru secara online era pandemi covid 19 di SMP Negeri 3 Palangka Raya. Permasalahan mengangkat manajemen penerimaan peserta didik baru yang dilakukan secara online. Untuk memetakan permasalahan manajemen tersebut, peneliti menyoroti aspek perencanaan (planning), pengorganisasian (organizing), pemimpinan (leading), pengarahan (directing), penggerakan (actuating), serta pengendalian (controling). Metode penelitian menggunakan pedekatan kualitatif, yang menghasilkan data deskripsi, dilakukan dengan cara observasi, dokumentasi dan wawancara terhadap Kepala Sekolah dan Guru yang terlibat dalam Panitia penerimaan peserta didik baru di SMP Kristen dan SMP Negeri 3 Palangka Raya Tahun pelajaran 2020/2021.
\end{abstract}

Kata kunci: manajemen; peserta didik baru; online

\section{Pendahuluan}

Sumber daya manusia bermuara pada pendidikan, karena melalui pendidikan dapat membawa manusia keluar dari kebodohan, keterbelakangan dan kemiskinan. Dengan kata lain semakin tinggi pendidikan yang dimiliki seseorang maka semakin tinggi pula wawasan, pandangan, dan kecerdasan intelektualnya, yang menandakan bahwa sumber daya yang dimilikinyapun semakin tinggi. Sebagaimana yang dikatakan oleh Ki Hadjar Dewantara, “Pendidikan adalah upaya untuk memajukan 
budi pekerti (kekuatan batin), pikiran (intellect), dan jasmani anak-anak, selaras dengan alam dan masyarakatnya."1

Berdasarkan informasi di atas, bahwa melalui pendidikanlah budi pekerti seseorang akan lebih baik, lebih maju bila dibandingkan dengan orang yang tidak berpendidikan. Dan orang yang berpendidikan yang memiliki kecerdasan intelektual, yang ditandai dengan cara berbicara yang sistematis, yang mudah dipahami oleh orang lain, yang tentunya juga memiliki sikap dan perilaku yang terpuji, mudah menyesuaikan dirinya dalam segala hal dan keadaan, mampu memanfaatkan alam sebagai sumber kehidupan secara bijaksana. Senada dengan pendapat tersebut, Komisi Delor menyatakan Pendidikan yang baik adalah pendidikan yang memberi paspor kehidupan bagi orang muda, yaitu kemampuan untuk memahami diri sendiri, orang lain, dan nasib bangsanya. ${ }^{2}$ Jadi pendidikan yang baik adalah pendidikan yang mampu menuntun anak muda untuk mengenal siapa dirinya, potensi apa yang ada dalam dirinya, sehingga ia mampu tumbuh dan berkembang seturut dengan potensi dirinya, yang pada akhirnya ia mampu dan menyadari bahwa ia hidup berdampingan dengan orang lain, yang harus dihormati dan dihargai hak-hak orang lain, sehingga terwujud kehidupan yang harmonis antara sesama manusia, yang merupakan bagian dari masyarakat, bangsa dan negara. Yang lain yang tidak kalah penting adalah diharapkan ia mampu mengambil peran dalam menentukan nasib bangsa dan negaranya dikemudian hari, sehingga tercipta ketahanan bangsa dan negara yang handal dan mapan.

Cara mengikuti pendidikan telah diterapkan dengan sistem belajar secara konvesional maupun cara belajar jarak jauh. Cara belajar secara konvensional adalah cara belajar yang umum di lembaga pendidikan, di mana lembaga pendidikan telah menyediakan sekolah sebagai tempat belajar, sebagai tempat pertemuan (Tatap muka) antara pendidik dengan peserta didik secara terjadwal. Sedangkan cara belajar jarak jauh, yaitu cara belajar dengan menggunakan jasa internet, atau menggunakan modul. Di mana antara pendidik dengan peserta didik tidak selalu bisa bertemu, tetapi hanya ada waktu-waktu tertentu saja, misalnya pertemuan hanya sekali dalam satu semester, kemudian diberikan modul untuk belajar sendiri, kalau ada masalah selama belajar, peserta didik bisa menghubungi pendidiknya melalui hand phone, whatsApp (WA), Twitter, e mail, dan sarana yang lain dalam layanan internet. Hal ini telah lama dilakukan oleh Lembaga pendidikan Tinggi, Yaitu Universitas Terbuka, Sistem belajarnya adalah Sistem belajar Jarak Jauh. Sistem Penerimaan Mahasiswa baru dan Ujianyapun telah menggunakan jasa internet secara online.Dengan demikian cara

${ }^{1}$ Agus Wibowo, Manajemen PendidikanKarakter di Sekolah: Konsep dan praktik implementasi (Jakarta: Penerbit Pustaka Pelajar, 2013), 34.

2 Ibid. 
belajar, baik secara konvensional maupun secara online bukanlah hal yang asing bagi masyarakat, terutama bagi kalangan menengah ke atas.

Namun pada akhir tahun 2019 dunia dihebahkan dengan serangan virus pandemi Covid 19. Virus ini pada akhirnya sampai juga di Indonesia, tepatnya awal maret 2020, dengan adanya warga masyarakat terinfeksi dan meninggal dunia akibat virus pandemi covis 19. Untuk menghadang arus penyebaran virus tersebut Pemerintah memberlakukan peraturan dan kebijakan. Dampaknya adalah penutupan aktivitas di kantor, tempat-tempat ibadah, bahkan aktivitas sosialpun drastis menurun, sehingga banyak warga masyarakat kehilangan mata pencaharianya. Kemudian aktivitas sekolahpun ditutup, semua beraktivitas di rumah, belajar dan beribadah dari rumah.

Dampak pandemi covid 19, sendi-sendi kehidupan dalam berbangsa dan bernegara, terkesan mati suri, yang biasanya aktivitas masyarakat ramai dan lancar, mendadak sepi, aktivitas di kantor sebagian ditutup, kegiatan sosialpun tidak berjalan sebagaimana mestinya. Aktivitas sekolah juga sepi, hal ini dialihkan dari cara belajar secara konvensional ke cara belajar secara online, dengan berbagai fasilitas yang ada. Di saat ini pada saat penelitian berlangsung, hampir semua lembaga pendidikan, baik pendidikan dasar, menengah sampai pendidikan tinggi, penerimaan peserta didik baru semua menggunakan sistem online.

Berdasarkan permasalahan tersebut di atas, maka yang menjadi perhatian dalam penelitian adalah: Bagaimana perencanaan penerimaan peserta didik baru secara online di SMP Kristen dan SMP Negeri 3 Palangka Raya? Apa saja jalur pelaksanaan penerimaan peserta didik baru? Bagaimana proses penentuan kelulusan penerimaan peserta didik baru? Apakah pengawasan terlaksana dengan baik?

\section{Metode}

Penelitian ini menggunakan pendekatan kualitatif. "Kualitatif adalah metode penelitian yang digunakan untuk meneliti pada kondisi objek yang alamiah, di mana peneliti sebagai instrumen kunci". Sugiyono (2005:1). Subjek penelitian ini adalah Kepala Sekolah, dan Guru-guru sebagai Panitia Penerimaan Peserta Disik Baru SMP Negeri 3 Palangka Raya Tahun pelajaran 2021/2022. Teknik pengumpulan data adalah dengan melakukan observasi, dokumentasi dan wawancara. Sedangkan analisis data dilakukan dengan cara sebelum ke lapangan dan setelah selesai di lapangan. Trianggulasi untuk menguji validitas, kredibilitas data dengan cara pengecekan data dengan berbagai sumber, dan dengan berbagai cara dan waktu. 


\section{Hasil dan Pembahasan}

\section{Manajemen Penerimaan Peserta Didik Baru}

Istilah manajemen dalam bahasa Inggris "manager" yang berarti menangani, atau dalam bahasa indonesia disebut manajemen atau pengelolaan. ${ }^{3}$ Sementara itu pengertian manajemen menurut Decenzo, yaitu suatu proses efisiensi dalam pencapaian tujuan organisasi dengan melibatkan orang-orang. ${ }^{4}$ Dari kutipan tersebut dapat dipahami bahwa esensi manajemen adalah proses efisiensi. Efisien artinya tepat, cepat dan mampu. Jadi manajemen merupakan proses menempatkan orang-orang pada suatu organisasi sesuai dengan latar belakang keahlianya dan dalam waktu yang relatif singkat, serta memanfaatkan dana/biaya secara efisien untuk mencapai tujuan yang telah ditetapkan. Senada dengan pendapat tersebut, Henry menjelaskan bahwa manajemen sebagai proses pendayagunaan bahan baku dan sumber daya manusia, untuk mencapai tujuan yang ditetapkan. ${ }^{5}$ Lebih lanjut menurut Massie Joseph, manajemen sebagi kelompok khusus orang-orang yang tugasnya mengarahkan daya upaya dan aktivitas orang lain pada sasaran yang sama, atau secara singkat manajemen adalah menjalankan sesuatu melalui orang lain. ${ }^{6}$

Dari beberapa difinisi manajemen di atas dapat disimpulkan bahwa hakekat manajemen merupakan proses efisiensi untuk menempatkan orang-orang yang berkompeten dalam bidangnya, pemanfataan waktu, tenaga dan biaya secara tepat dan untuk menggolkan maksud tersebut, peran seorang manager untuk memberikan pengarahan dan pengawasan agar aktivitas organisasi dapat terlaksana dengan baik, guna mewujudkan tujuan bersama.

\section{Fungsi Manajemen}

Fungsi manajemen penerimaan peserta didik baru dapat diuraikan dalam beberapa aspek berikut. Apek tersebut adalah pertama, perencanaan (planning). Kedua, pengorganisasian (organizing). Ketiga, pemimpinan (leading). Keempat, pengarahan (directing). Kelima, penggerakan (actuating). Keenam, pengendalian (controling). ${ }^{7}$

Fungsi dari manajemen di atas dapat diuraikan sebagai berikut: pertama, perencanaan. Perencanaan adalah kegiatan yang dilakukan setiap organisasi untuk melakukan analisis berbagai kekuatan, kelemahan, peluang dan tantangan yang ada dalam lembaga tersebut, guna merumuskan tujuan yang ingin dicapai. Menurut

\footnotetext{
${ }^{3}$ Husaini Usman, Manajemen, Teori, Praktik dan Riset Pendidikan (Jakarta: Bumi Aksara, 2006), 3.

${ }^{4}$ D. A. Decenzo dan Robbins S. P., Human Resource Management (New York: John Wiley \& Sons, Inc., 1990), 5.

${ }^{5}$ Henry Simamora, Manajemen Sumber Daya Manusia (Yogyakarta: STIE YKPN, 2004$), 4$.

6 Joseph L. Massie, Dasar-dasar Manajemen (Jakarta: Erlangga, 1983), 4.

7 Onisimus Amtu, Manajemen Pendidikan di Era Otonomi Daerah, Konsep, Strategi, dan Implementasi (Bandung: Alfabeta, 2013), 30.
} 
Benowitz, sebelum seorang manager menangani salah satu fungsi dari managemen, terlebih dahulu ia membuat rencana. ${ }^{8}$ Perencanaan juga merupakan langkah awal yang harus dilakukan seorang manager. Perencanaan meliputi penetapan tujuan, penentuan alokasi sumber daya penjadwalan, tugas, dan tindakan lain. Organisasi yang baik adalah suatu organisasi yang memiliki perencanaan yang baik, yang di dalamnya terkandung visi, misi dan tujuan organisasi, serta strategi untuk mencapai tujuan yang telah dirumuskan. Seturut dengan pengertian tersebut, perencanaan penerimaan peserta didik baru, akan melakukan analisis kebutuhan, yaitu penetapan siswa yang dibutuhkan oleh lembaga pendidikan (Sekolah). ${ }^{9}$ Adapun kegiatan yang dilakukan dalam menetapkan analisis kebutuhan peserta didik baru adalah: daya tampung kelas atau jumlah kelas yang tersedia, serta rasio murid dan guru.

Lebih lanjut, pada awal tahun ajaran, yang ditandai penerimaan peserta didik baru, langkah awal yang dilakukan oleh sekolah adalah menetapkan daya tampung sekolah berdasarkan ketersediaan ruangan kelas yang kosong yang akan ditempati peserta didik baru, yang kedua adalah mentapkan jumlah peserta didik pada setiap kelas yang tersedia. Berdasarkan anjuran pemerintah penetapan jumlah peserta didik /ruangan adalah: antara 40-45 orang setiap kelas, sedangkan ukuran kelas secara teoritik berjumlah 25-30 orang perkelas. Dengan demikian, ideal murid guru adalah 1:30. Artinya, setiap guru membimbing 30 orang murid. Apabila berpijak dengan pendapat tersebut, maka penerimaan peserta didik baru berdasarkan jumlah kelas yang ada, yang kososng yang telah ditinggalkan oleh kakak kelasnya yang telah meneyelesaikan studinya di sekolah tersebut. Katakanlah kakak kelas yang ujian tahun ajaran sebelumnya berjumlah tiga kelas, dengan daya tampung 30 orang setiap kelas, jumlah peserta didik baru yang akan diterima pada awal tahun pelajaran ini adalah 3 × $30=90$ orang peserta didik baru.

Kedua, pengorganisasian. Organisasi selalu diartikan sebagai berbagai komponen dalam suatu struktur dan sistem kerja yang terus bergerak seirama dengan sasaran tujuan yang ingin dicapai. ${ }^{10}$ Mengorganisasikan merupakan proses mempekerjakan dua orang atau lebih untuk bekerja sama dalam cara terstruktur guna mencapai sasaran spesifik atau beberapa sasaran. Dengan kata lain pengalokasian pekerjaan, wewenang, dan sumber daya diantara anggota organisasi, sehingga mereka dapat mencapai tujuan. Dapat dipahami bahwa organisasi merupakan kegiatan rekrutmen orang-orang untuk menempati posisi tertentu sesuai dengan keahlian dan mampu bekerja sama dan memaksimalkan sumber daya yang ada guna mewujudkan tujuan yang telah ditetapkan. Dalam kaitanya dengan penerimaan

${ }^{8}$ Z. A. Benowitz, Cliffs Quick Review Principles of Management (New York: Hungry Minds, Inc., 2001), 47.

${ }^{9}$ Tim Dosen Administrasi Pendidikan Universitas Pendidikan Indonesia 2014, Manajemen Pendidikan (Bandung: Alfabeta, 2014), 207.

${ }^{10}$ Amtu, Manajemen Pendidikan di Era Otonomi Daerah, 47. 
peserta didik baru adalah kegiatan untuk merekruit para pegawai untuk menempatkan posisi tertentu yang terbentuk sebuah Panitia. Yang sering disebut dengan Penerimaan Peserta Didik Baru.

Ketiga, kepemimpinan. Kehadiran seorang pemimpin memiliki pengaruh yang cukup besar dalam menentukan keberhasilan atau kesuksesan suatu organisasi. John Adair dalam Amtu mengatakan bahwa pemimpin adalah suatu hubungan antara orang-orang dalam situasi tertentu. ${ }^{11}$ Artinya seorang pemimpin yang ideal dan baik adalah seorang pemimpin yang memiliki kemampun menjadi penyambung lidah, yang mampu menjalankan aspirasi anggotanya sehingga cita-cita organisasi akan tercapai. Ada sepuluh ciri utama bagi keberhasilan kepemimpinan, yaitu: pemimpin mengelola cita-cita untuk orang lain; pemimpin tidak takut gagal; pemimpin mendorong kilas balik untuk memahami apa yang ada di masa depan; pemimpin menerima perbedaan pendapat; pemimpin memiliki faktor optimisme yang mulia, beriman dan memiliki harapan; pemimpin memahami setiap kesalahan pengelolaan; pemimpin memiliki kepekaan; pemimpin memiliki visi; pemimpin memiliki pemahaman yang kuat tentang keterkaitan para pemangku kepentinga; serta pemimpin sangat efektif untuk membangun aliansi strategis dan kemitraan. Itulah gambaran seorang pemimpin yang ideal yang mampu membawa perubahan menuju kemajuan untuk mewujudkan tujuan organisasi, yang di dalamnya terjalin kerja sama yang baik, ketentraman, kedamaian dan keharmonisan dalam suatu organisasi.

Keempat, pengarahan. Salah satu tugas pemimpin atau manager adalah memberikan arahan, agar stap benar-benar mengerti akan tugas yang diembankan kepadanya, sehingga semua kegiatan dapat terlaksana dengan baik. Stoner dalam Amtu, mendefinisikan pengarahan yaitu, fungsi manajemen yang berusaha memberi bimbingan, saran, perintah atau instruksi kepada bawahan melaksanakan tugas masing-masing, agar tugas dapat dilaksanakan dengan baik dan benar-benar tertuju pada tujuan yang telah ditetapkan semula. ${ }^{12}$ Pengarahan juga merupakan proses mempengarohi perilaku masyarakat melalui motivasi, komunikasi, kelompok dinamika, kepemimpinan dan disiplin. Dengan demikian, dapat disimpulkan bahwa pengarahan merupakan usaha yang dilakukan pimpinan terhadap bawahan, berupa bimbingan, ajakan atau perintah, motivasi, komunikasi terhadap hal-hal yang belum dipahami oleh bawahan, sehinga tugas dan tanggung jawab yang dibebankan dapat dimengerti dan dilaksanakan dengan baik sesuai dengan tujuan yang telah ditetapkan.

Kelima, penggerakan. Penggerakan (actuating) merupakan realisasi dari perencanaan yang telah dirumuskan sebelumnya, guna mencapai tujuan yang ditetapkan. Penggerakan dalam manajemen penerimaan peserta didik, setelah

\footnotetext{
${ }^{11}$ Ibid., 52.

12 Ibid., 55.
} 
melakukan analisis kebutuhan peserta didik, maka pelaksanaanya adalah melakukan rekruitmen, seleksi dan orintasi peserta didik. ${ }^{13}$ Ketiga tahap tersebut di atas dapat diuraikan sebagai berikut: rekruitmen peserta didik di sebuah lembaga pendidikan (Sekolah) pada hakekatnya adalah merupakan proses pencarian, menentukan dan menarik pelamar yang mampu untuk menjadi peserta didik. Rekruitmen peserta didik ini berlangsung awal tahun ajaran, setelah sekolah tersebut meluluskan peserta didik pada tahun pelajaran sebelumnya. Penerimaan peserta didik baru ini merupakan tindak lanjut dari analisis kebutuhan peserta didik, yang tertuang dalam perencanaan. Adapun langkah-langkah penerimaan peserta didik baru adalah: 1) Pembentukan Panitia Penerimaan Peserta didik baru. 2) Pembuatan atau pemasangan pengumuman penerimaan peserta didik baru, yang dilakukan secara terbuka. Sedangkan isi pengumuman tersebut antara lain: (1) Gambaran singkat lembaga pendidikan (Sekolah), meliputi sejarah sekolah, Visi dan misi sekolah, kelengkapan fasilitas sekolah, tenaga kependidikan, dan hal-hal lain yang dianggap perlu. (2) Persyaratan pendaftaran penerimaan peserta didik baru. (3) Cara mendaftar. (4) Waktu pendaftaran. (5) Tempat pendaftaran. (6) Uang pendaftaran. (7) Waktu dan tempat seleksi, dan 8). Pengumuman hasil seleksi.

Keenam, pengendalian. Pengendalian merupakan kegiatan yang dilakukan oleh seorang pimpinan atau manager dalam sebuah organisasi untuk mengetahui efektivitas dan efisiensi kinerja para karayawan. Pengendalian merupakan proses empat langkah pembentukan standar kinerja berdasarkan tujuan perusahaan, pengukuran dan pelaporan kinerja aktual, membandingkan dan mengambil tindakan korektif atau preventif yang diperlukan dalam suatu organisasi. Setelah sumber daya yang dikumpulkan ke dalam sebuah struktur yang koheren, maka diperlukan pengendalian untuk mengelola struktur selama suatu kegiatan berjalan. Pengendalian juga mencakup pembentukan struktur pelaporan pada titik tertentu melalui siklus hidup proyek.

\section{Perencanaan dan pengorganisasian Penerimaan Peserta Didik Baru}

Hasil penelitian menunjukan bahwa SMP Negeri 3 Palangka Raya, telah memiliki perencanaan penerimaan peserta didik baru, tahun pelajaran 2021/2022. Namun sebelum menetapkan perencanaan penerimaan peserta didik baru, ada dua hal yang peril dipertimbangankan, yaitu: pertama, memperhatikan Rencana Strategis dan Program Kerja Sekolah, yang telah lama dibuat dan ditetapkan oleh Sekolah semenjak Kepala Sekolah menduduki jabatan sebagai kepala sekolah. Dimana fungsi Rencana Strategis ini merupakan pedoman kerja bagi sekolah sekolah. Kedua, pedoman Pelaksanaan Penerimaan Peserta Didik Baru, yang biasanya dikeluarkan

13 Tim Dosen, 208. 
oleh Dinas Pendidikan dan Kebudayaan, yang ditandatangani oleh Pemerintah Kota/ kabupaten atau Pemerintah Provinsi.

Berdasarkan kedua hal tersebut, maka Kepala Sekolah mengundang tenaga pendidik dan tenaga kependidikan dalam sebuah rapat, untuk membahas perencanaan peserta didik baru, Adapun yang dibahas dalam perencaan penerimaan peserta didik baru tersebut meliputi: pertama, membahas jumlah peserta didik yang telah lulus pada tahun pelajaran sebelumnya. Kedua, membahas daya tampung sekolah atau jumlah rombel (rombongan belajar) setiap kelas yang akan ditempati peserta didik baru. Ketiga, membahas jumlah peserta didik setiap rombel. Keempat, mempertimbangan rasio siswa dan guru seperti yang tertuang dalam Peraturan Menteri Pendidikan dan Kebudayaan Nomor 17 Tahun 2017 tentang Peserta didik Baru.

Tindak lanjut dari perencanaan tersebut adalah pengorganisasiaan. Menurut Stoner, mengungkapkan bahwa mengorganikan adalah proses mempekerjakan dua orang atau lebih untuk bekerja sama dalam cara terstruktur guna mencapai sasaran yang telah ditetapkan. Berdasarkan pengertian organisasi tersebut, sekolah membentuk Panitia Penerimaan Peserta didik baru, yang ditanda dengan keluarnya Surat Keputusan Kepala Sekolah. Di mana dalam Keputusan tersebut, tercantum bahwa Kepala Sekolah bertindak sebagai penanggung jawab kegiatan, dan guru-guru yang lain yang dipandang kompeten, ditunjuk sebagai Ketua, Sekretaris dan Bendahara, dan dibantu oleh guru yang lain serta dari tenaga tata usaha yang membantu tugas-tugas panitia dalam bidang operator dan administrasi. Adapun tugas Panitia Penerimaan peserta didik baru adalah membuat program kerja, yang meliputi: pertama, melakukan sosialisasi penerimaan peserta didik baru, kepada masyarakat, baik melalui surat edaran, mapun pemasangan spanduk yang pada tempat-tempat strategis, maupun melalui sosial media. Kedua, menentukan jalur penerimaan peserta didik baru. Ketiga, membuat jadwal penerimaan peserta didik baik, yang diawali dengan pendaftaran, penjaringan/seleksi dan menyampaikan pengumuman penerimaan peserta didik baru. Keempat, membuat laporan kepada kepala Sekolah.

\section{Pemimpinan dan Pengarahan}

Kehadiran seorang pemimpin sangat besar pengaruhnya terhadap keberhasilan sebuah pekerjaan dalam sebuah organisasi. Mengingat penangung jawab secara menyeluruh ada di tanganya, hal in dipertegas dalam salah satu uraian tugas yang tertera dalam Keputusan Kepala Sekolah, yang menyatakan bahwa: penanggung jawab seluruh kegiatan PPDB; menerima laporan kemajuan/kendala selama pelaksanaan kegiatan dari Ketua Panitia PPDB; penerima laporan hasil seleksi PPDB; 
serta melaporkan seluruh pelaksanaan kegiatan PPDB kepada Kepala Dinas Pendidikan.

Sedangkan pengarahan erat kaitanya dengan Tugas pemimpin dalam hal ini adalah Kepala sekolah,untuk memastikan bahwa pelimpahan yang diberikan kepada kelompok tertentu, seperti dalam Panitia PPDB. Di sini tugas Kepala sekolah adalah memberikan arahan atau petunjuk tentang pekerjaan atau kegiatan yang akan dilakukan selama proses PPDB berlangsung, sehingga Panitia paham betul apa yang menjadi tugas dan tanggung jawabnya, Hal ini tertuang dalam Keputusan Kepala Sekolah, di mana salah satu tugas Penanggung jawab adalah: Memberi informasi kepada media cetak, elektronik maupun lembaga terkait bila diperlukan yang berhubungan dengan pelaksanaan PPDB. Arahan atau petunjuk yang diberikan oleh Kepala Sekolah sebagai Pemimpin di Sekolah, tidak hanya terbatas memberikan arahan ke dalam, tetapi juga ke luar, baik kepada masyarakat, orang tua wali siswa maupun kepada media masa dan lembaga/instansi Pemerintah. Hal ini dimaksudkan supaya setiap masalah yang ada, Kepala sekolah hadir untuk memberikan arahan dan petunjuk sesuai dengan peraturan yang berlaku, sehingga setiap masalah yang ada terpecahkan dan menemukan solusinya. Hal tersebut menggambarkan sepuluh ciri utama bagi keberhasilan kepemimpinan, yang disamapikan oleh Evan, yaitu: pemimpin pengelola cita-citauntuk orang lain; pemimpin tidak takut gagal; pemimpin mendorong kilas, baik untuk memahami apa yang ada di masa depan; pemimpin menerima perbedaan pendapat; pemimpin memiliki faktor optimisme yang mulia, beriman dan meiliki harapan; pemimpin memahami setiap kesalahan pengelolaan; pemimpin memiliki kepekaan; pemimpin memiliki visi; pemimpin memiliki pemahaman yang kuat tentang keterkaitan para pemangku kepentingan; pemimpin sangat efektif untuk membangun aliansi strategis dan kemitraan.

\section{Penggerakan}

Penggerakan identik dengan pelaksanaan. Pelaksanaan PPDB tahun ini menggunakan 4 (empat) jalur, sebagaimana tertuang dalam Keputusan Wali Kota Palangka Raya, nomor 188.45/245/ 2021 tentang Pedoman Pelaksanaan Peserta Didik Baru Pada Taman Kanak-kanak, Sekolah Dasar dan Sekolah Menengah Pertama Kota Palangka Raya TahunPelajaran 2021/2022, dalam pasal 12 menyatakan bahwa: Ayat 1 Pendaftaran PPDB dilaksanakan melalui jalur sebagai berikut: zonasi; afirmasi; prestasi; serta perpindahan tugas orang tua/wali. Dalam pasal 15: 1 dijelaskan bahwa: "Jalur zonasi sebagaimana dimaksud dalam pasal 12:1 huruf a diperuntukan bagi peserta didik yang berdomisili di dalam wilayah zonasi. Untuk SD radius 3 (tiga) KM dan SMP radius 5 (lima) KM. Dalam pasal 15:3 menjelaskan bahwa, domisili calon peserta didik sebagaimana dimaksud pada ayat 1 berdasarkan alamat pada kartu 
keluarga yang diterbitkan paling singkat 1 (satu) tahun sejak tanggal pelaksanaan PPDB.

Dalam pasal 16:1 menyatakan bahwa jalur afirmasi sebagaimana dimaksud dalam pasal $12: 1$ hurup b diperuntukan bagi peserta didik yang berasal dari keluarga ekonomi tidak mampu. Dalam Pasal 16 :2 dijelaskan bahwa: Peserta didik yang berasal dari keluarga ekonomi tidak mampu sebagaimana dimaksud pada ayat 1 , dibuktikan dengan bukti keikutsertaan peserta didik dalam program penangan program tidak mampu dari Pemerintah Pusat atau pemerintah Daerah.

Dalam pasal 17:1 menyatakan bahwa jalur prestasi dimaksud dalam pasal 12:1 huruf c ditentukan berdasarkan hasil perlombaan dan/atau penghargaan di bidang akademik maupun nonakademik pada tingkat internasional, tingkat nasional, Tingkat Provinsi/Kabupaten/Kota. Dalam pasal 17:2, menjelaskan bahwa bukti atas prestasisebagaimana dimaksud pada ayat 1 , diterbitkan paling singkat 6 (enam) bulan dan paling lama 3 (tiga) tahun sejak tanggal pendaftaran PPDB.

Dalam pasal 18, jalur perpindahan tugas orang tua/wali, menyatakan bahwa: (1) Jalur perpindahan tugas orang tua/wali siswa sebagaimana dimaksud dalam pasal 12:1 huruf d ditujukan bagi calon peserta didik yang berdomisili di luar zonasi sekolah yang bersangkutan; (2) Perpindah tugas se bagaimana dimaksud pada ayayt (1), dibuktikan dengan surat penugasan dari instansi, lembaga, kantor, atau perusahaan yang mempekerjakan. (3) Kuota jalur perpindahan tugas orang tua/wali dapat digunakan untuk anak tenaga pendidik dan tenaga kependidikan yang bertugas di sekolah tersebut.

Itulah jalur penerimaan PPDB di SMP 3 Palangka Raya tahun pelajaran 2021/2022. Yang menggunakan pendaftaran secara online hanya jalur zonasi dengan memenuhi berbagai persyaratan yang telah ditetapkan oleh sekolah melalui Panitia PPDB. Sedang ketiga jalur yang lain (Jalur afirmasi, Prestasi dan Mengikuti orang tua/wali yang pindah tempat kerja) pendaftaran dilakukan secara luring /luar jaringan (ofline). Adapun langkah-langka pendaftaran secara online (Zonasi) adalah sebagai berikut: calon peserta didik menyiapkan berkas persyaratan pendaftaran; calon peserta didik Mengakses laman situs PPDB online Kota Palangka Raya; calon peserta didik Mengunggah/upload dokumen persyaratan (asli), pastikan bekas asli jelas dan mudah terbaca; calon peserta didik memilih sekolah tujuan; calon peserta didik mencetak bukti pengajuan pendaftaran PPDB online; operator sekolah melakukan verifikasi pendaftaran secara online; calon peserta didik melihat hasil seleksi secara online di (kota palangkaraya.siap-ppdb.com).

Sedangkan pendaftara secara luring/ogline, yaitu jalur seleksi afirmasi, prestasi dan perpindahan orang tua/wali siswa adalah sebagai berikut: calon peserta didik menyiapkan berkas persyaratan pendaftaran; calon peserta didik mengambil formulir pendaftaran, biodata isiansesuai jalur seleksi pada loket yang telah 
ditentukan; calon peserta didik melengkapi berkas persyaratan pendaftaran; calon peserta didik memasukan berkas persyaratan pendaftaran sesuai loket jalur seleksi yang telah ditentukan; petugas loket melakukan verifikasi ; calon peserta didik menerima bukti penyerahan berkas pendaftaran; calon peserta didik melihat pengumuman hasil seleksi (luring/di sekolah).

\section{Pengendalian}

Pengendalian dilakukan oleh seorang Pimpinan, dalam hal ini adalah Kepala Sekolah. Pengendalian dilakukan baik secara rutin atau secara periodik, untuk memastikan bahwa kegiatan pelaksanaan PPDB dengan baik dan lancar. Dengan kata lain dengan adanya tindakan pengendalian itu diharapkan kegiatan dapat terlaksana secara efektif dan efisien. Berdasarkan pengamatan peneliti selama pelaksanaan PPDB berlangsung, tidak kendalan yang berarti, mengingat Kepala Sekolah selalu hadir di sekolah, sehingga sekecil apapun permasalahan yang muncul segera ditanggapi dan dapat diselesaikan dengan baik.

Disamping Kepala Sekolah yang melakukan pengendalian selama PPDB berlangsung, juga dibantu dari Dinas Pendidikan Kota Palangka Raya, yaitu pengawas sekolah. Untuk memastikan bahwa pelaksanaan PPDB telah dilakukan dengan baik dan lancar, maka pengawas ini sekaligus menyampaikan angket PPDB untuk diisi oleh Panitia ataupun langsung diisi oleh pengawas berdasarkan pengamatan yang dia langsung melihat keadaan yang sebenarnya.

\section{Implikasi}

Implikasi dari penelitian ini ialah manajemen penerimaan peserta didik baru di SMP Negeri 3 Palangka Raya yang dilakukan secara online terlaksana dengan baik. Kemudian, diharapkan kepada masyarakat, orang tua dari anak-anak peserta didik yang merupakan pelanggan sekolah yang menyelenggarakan penerimaan peserta didik baru secara online dapat mengikutinya dengan sesuai dengan prosedur dan ketentuan yang berlaku. Selanjutnya, fakta bahwa saatnya menerima belajar dan membiasakan diri beraktivitas dari rumah dengan peralihan pola kerja secara konvensional ke pola hidup yang berlandaskan dalam jaringan (online).

\section{Rekomendasi untuk Penelitian Lanjutan}

Penelitian ini fokus mengevaluasi menajemen penerimaan peserta didik baru secara online di SMP Negeri 3 Palangka Raya. Penelitian lanjutan dapat meneliti topik sejenis dengan mengambil lokasi penelitian di beberapa sekolah untuk memperkaya variasi dan komplesitas masalah yang ditemukan di lapangan. Termasuk meneliti hasil atau tingkat kepuasan pengguna sistem penerimaan peserta didik secara online. 


\section{Kesimpulan}

Berdasarkan analisis data dan pembahasanya hasil penelitian tentang manajemen penerimaan peserta didik secara online di era pandemi covid 19 di SMP Negeri 3 Palangka Raya, maka peneliti menyimpulkan bahwa: fungsi manajemen, yang meliputi: perencanaan, pengorganisasian, pemimpinan, pengarahan, penggerakan dan pengendalian terlaksanan dengan baik. Sehingga penerimaan peserta didik baru dilakukan sesuai dengan perencanaan, prosedur dan peraturan yang berlaku. Berdasarkan Keputusan Walikota Palangka Raya, Tahun 2021 tentang Pedoman Pelaksanaan Penerimaan Peserta Didik Baru pada Taman kanak-kanak, Sekolah dasar, Sekolah Menengah Pertama Kota Palangka Raya salah satu sekolah yang ditunjuk dan dipercayakan untuk menyelenggarakan penerimaan peserta didik baru melalui mekanisme daring/dalam jaringan (online); jalur penerimaan peserta didik baru, meliputi: zonasi, afirmasi, prestasi, dan perpindahan tugas orang tua/wali.

\section{Rujukan}

Amtu, Onisimus. Manajemen Pendidikan di Era Otonomi Daerah, Konsep, Strategi, dan Implementasi. Bandung: Alfabeta, 2013.

Benowitz. Z. A. Cliffs Quick Review Principles of Management. New York: Hungry Minds, Inc., 2001.

Decenzo, D.A. dan S. P. Robbins. Human Resource Management. NewYork: John Wiley \& Sons, Inc., 1990.

Engkoswara dan Aan Komariah. 2012, Administrasi pendidikan. Bandung: Alfabeta Bandung, 2012.

Massie, Joseph L. Dasar-dasar Manajemen. Jakarta: Erlangga, 1983.

Nurdin Diding \& Imam Sibaweh. 2015, Pengelolaan Pendidikan Dari teori menuju implementasi, Penerbit Raja Grafindo Persada Jakarta.

Simamora, Henry. Manajemen Sumber Daya Manusia. Yogyakarta: STIE YKPN, 2004.

Tim Dosen Administrasi Pendidikan Universitas Pendidikan Indonesia.2014, Manajemen Pendidikan. Bandung: Alfabeta, 2014.

Usman, Husaini. Manajemen: Teori, Praktik dan Riset Pendidikan. Jakarta: Bumi Aksara, 2006.

Wibowo, Agus. Manajemen Pendidikan Karakter di Sekolah: Konsep dan praktik implementasi. Bandung: Pustaka Pelajar, 2013. 